\title{
Short Communication: Antibacterial effect of red betel (Piper crocatum) extract in combination with vancomycin against Staphylococcus aureus
}

\author{
YUSTINA SRI HARTINI ${ }^{1, \vartheta}$, LAURENTIUS HARTANTO NUGROHO ${ }^{2, \bullet \bullet}$ \\ ${ }^{1}$ Faculty of Pharmacy, Universitas Sanata Dharma. Jl. Paingan, Maguwoharjo, Depok, Sleman 55282, Yogyakarta, Indonesia. \\ Tel.: +62-274-883037, Fax.: +62-274-886529, ^email: yustinahartini@usd.ac.id \\ ${ }^{2}$ Faculty of Biology, Universitas Gadjah Mada. Jl. Teknika Selatan, Sleman 55281, Yogyakarta, Indonesia. \\ Tel.:+62-271-580839, Fax.: +62-271-6492355, ^vemail: hartantonugroho2005@ugm.ac.id
}

Manuscript received: 13 April 2020. Revision accepted: 24 June 2020

\begin{abstract}
Hartini YS, Nugroho LH. 2020. Short Communication: Antibacterial effect of red betel (Piper crocatum) extract in combination with vancomycin against Staphylococcus aureus. Biodiversitas 21: 3271-3274. The occurrence of bacterial resistance to a single antimicrobial compound has prompted the search for antimicrobials in the form of compound combinations. The current study was performed to show the antibacterial effect of red betel (Piper crocatum Ruiz \& Pav.) in combination with vancomycin against Staphylococcus aureus. The combination of the antibacterial compounds from plant with the antibacterial drug was expected to increase antibacterial activity resulted in the reduction of resistance. The interaction effect of extract and antibiotic combination was performed using the microdilution checkerboard method. The combination of red betel extract with vancomycin showed significantly ( $<<0.05$ ) greater inhibition growth of $S$. aureus compared to red betel or vancomycin alone. The addition of red betel extract to vancomycin reduced Minimum Inhibitory Concentration (MIC) vancomycin to be a-4 fold reduction against $S$. aureus. There was a synergistic effect of the red betel extract in combination with vancomycin against $S$. aureus. It is the potential result for future research on the infectious treatment of $S$. aureus resistant to vancomycin.
\end{abstract}

Keywords: Checkerboard, red betel extract, synergistic antibacterial, Staphylococcus aureus resistant

Abbreviations: MIC: Minimum Inhibitory Concentration; FICI: Fractional Inhibitory Concentration Index; MRSA: MethicillinResistant Staphylococcus aureus; VRSA: Vancomycin-Resistant Staphylococcus aureus

\section{INTRODUCTION}

The discovery of penicillin antibiotics from the fungus Penicillium notatum was no longer a finding that addresses the problem of infection, an increase in cases of Staphylococcus aureus infections in hospitals in the mid1940 s proved the need for new drugs to treat $S$ aureus. Furthermore, methicillin findings can eliminate most of the pandemic $S$. aureus infection. However, the following time, the strains of methicillin-resistant $S$. aureus (MRSA) were found (Chambers and DeLeo 2009). Vancomycin is an antibiotic that is then used to treat Methicillin-resistant S. aureus (MRSA). However, it was first reported in 1997 that $S$. aureus resistant to vancomycin (VRSA) (Leclerecq 2009). The disc diffusion method showed that 21 of 29 strains S. aureus were MRSA, of which 11 were VRSA (Hasan et al. 2016). The current problem of bacterial resistance to antibiotics suggests that a single compound has not been able to overcome bacterial infections of $S$. aureus, new antibacterial, or combination of compounds that may resolve bacterial resistance. The combination of compounds can have synergistic, additive, or antagonistic effects. Stronger antibacterial effects can be achieved by combining drugs. The increased effects of antibacterial activity on several pathogens from the combined natural ingredients indicate a synergistic effect due to the combination of the ingredients (Cheesmas et al. 2017; Semeniuc et al. 2013) Treatment with a combination of drugs has been used as an approach to overcome bacterial resistance, for example in the treatment of malaria and tuberculosis (Nosten and White 2007; Ramon-Garcia et al. 2011). The analyses on the result of the drug combination effect do support and enhance the discovery of drugs that display better selectivity and the possibility of overcoming drug resistance (Bulusu et al. 2016). In developing resistance agents in the area of bacterial resistance, many researchers have been developing the natural extract as materials especially from plant extract which were combined with antibiotics (Demetrio et al. 2015). Betel and red betel showed a variation in anatomical characteristics (Nugroho et al. 2019). Betel showed the greatest antibacterial activity among 12 medicinal plants tested against Gram-positive and Gram-negative bacteria resistant to various drugs (Aldulaimi 2017). Antibacterial activity of red betel (Piper crocatum Ruiz \& Pav.) has been reported Kusuma et al. (2016). There have been no previous studies on the antibacterial effect of the combination of red betel extract with vancomycin. In this study, we aimed to determine the antibacterial effect of red betel extract and vancomycin combination against $S$. aureus. 


\section{MATERIALS AND METHODS}

The research material was red betel (Piper crocatum Ruiz \& Pav.) leaves taken from Sleman Yogyakarta Indonesia, vancomycin (Vancep®), and Staphylococcus aureus ATCC 25923 (bacteria concentration was equal to Mac Farland II standard), Mueller Hinton. Determination of red betel plant was done in the Faculty of Biology Universitas Gadjah Mada, Yogyakarta, Indonesia. Herbarium of Piper crocatum Ruiz \& Pav. is deposited at the Pharmacy Laboratory of the Faculty of Pharmacy, Sanata Dharma University, Yogyakarta, Indonesia.

Extraction with maceration followed by two times remaceration using methanol solvent. Evaporation was done with a rotary evaporator to obtain a thick red betel extract. Testing of antibacterial activity was performed by agar diffusion method, with test material in the form of solvent (A), vancomycin (B), red betel extract $150 \mathrm{mg} / \mathrm{mL}$ (C), the combination of vancomycin: extract (D, E, F). Determination on the antibacterial effect type of the test material combination was performed by microdilution checkerboard method to establish a single vancomycin MIC $\left(\mathrm{MIC}_{\mathrm{A}}\right)$, MIC of a single red betel extract $\left(\mathrm{MIC}_{\mathrm{B}}\right)$, $\mathrm{MIC}$ vancomycin in combination $\left(\mathrm{MIC}_{\mathrm{AB}}\right)$, MIC extract of red betel in combination $\left(\mathrm{MIC}_{\mathrm{BA}}\right)$. Fractional Inhibitory Concentration Index (FICI) values were obtained by the formula: $\left(\mathrm{MIC}_{\mathrm{A}} / \mathrm{MIC}_{\mathrm{AB}}\right)+\left(\mathrm{MIC}_{\mathrm{B}} / \mathrm{MIC}_{\mathrm{BA}}\right)$. A combination of vancomycin and extract is called synergy effect if the value of FICI $\leq 0.5$; whereas the term of indifference and antagonism are indicated if FICI> 0.5, and FICI> 4 respectively (Jain et al. 2011; Kosropanah et al. 2012).

\section{RESULTS AND DISCUSSION}

The results of the antibacterial activity test of red betel extract, vancomycin, and extract combination with vancomycin are shown in Figure 1. and Table 1.

\section{Discussion}

The results of the antibacterial activity test of red betel extract, vancomycin, and extract combination with vancomycin are shown in Figure 1. There is no visible growth inhibition zone of $S$. aureus in the solvent area (A), but the inhibition zone could be seen in the area of vancomycin (B), red betel extract $(\mathrm{C})$, and combination of extract and vancomycin $(\mathrm{D}, \mathrm{E}, \mathrm{F})$. The statistic test shows that there is a significant difference between inhibitory zone diameter of A and B, D, E, or F. It means that the test material of $\mathrm{B}, \mathrm{D}, \mathrm{E}$, and $\mathrm{F}$ showed antibacterial activity against $S$. aureus. Although the growth inhibition zone appears in $\mathrm{C}$, it is not significantly different to $\mathrm{A}$. The inhibitory zone diameter $\mathrm{D}, \mathrm{E}$, or $\mathrm{F}$ is significantly different to $\mathrm{B}$ and $\mathrm{C}$. It could be suggested that the combination of red betel extract and vancomycin showed greater antibacterial activity than single extracts or single vancomycin. The inhibitory zone diameter $\mathrm{D}$ and $\mathrm{E}$ were significantly different to $\mathrm{F}$. The combination of red betel extract and vancomycin with $150 \mathrm{mg} / \mathrm{mL}: 16 \mu \mathrm{g} / \mathrm{mL}$ and $300 \mathrm{mg} / \mathrm{mL}: 16 \mu \mathrm{g} / \mathrm{mL}$ ratio was significantly different to the combination of red betel extract and vancomycin with $600 \mathrm{mg} / \mathrm{mL}: 16 \mu \mathrm{g} / \mathrm{mL}$ ratio.

Table 1 shows the results of the antibacterial effect of red betel extract and vancomycin combination with the microdilution checkerboard method. Treatment with single vancomycin $(4 \mu \mathrm{g} / \mathrm{mL})$, and a single red betel extract $(12.5$ $\mathrm{mg} / \mathrm{mL}$ and $50 \mathrm{mg} / \mathrm{mL}$ ) were not significantly different from the solvent. Consecutive addition of $12.5 \mathrm{mg} / \mathrm{mL}, 50$ $\mathrm{mg} / \mathrm{mL}$, and $200 \mathrm{mg} / \mathrm{mL}$ red betel extract on vancomycin $(4 \mu \mathrm{g} / \mathrm{mL})$ resulted in significantly different antibacterial effects, as well as when the ret betel extract were added to vancomycin $16 \mu \mathrm{g} / \mathrm{mL}$. The addition of these three levels of red betel extract did not result in a significantly different antibacterial effect when the extracts added to vancomycin levels of $32 \mu \mathrm{g} / \mathrm{mL}$. The MIC value of red betel extract was at the concentration of $200 \mathrm{mg} / \mathrm{mL}$, MIC of vancomycin was at the concentration of $16 \mu \mathrm{g} / \mathrm{mL}$, whereas MIC of extract and antibiotic combination occurred in red betel extract and vancomycin at the ratio of $4 \mu \mathrm{g} / \mathrm{mL}: 12.5$ $\mathrm{mg} / \mathrm{mL}$.



Figure 1. Inhibition zones of extract, antibiotic, and combination of extract and antibiotic against $S$. aureus (A. Solvent, B. Vancomycin $(16 \mu \mathrm{g} / \mathrm{mL})$, C. Red betel extract $(150 \mathrm{mg} / \mathrm{mL})$, D. Combination Extract and Vancomycin $(150 \mathrm{mg} / \mathrm{mL}: 16 \mu \mathrm{g} / \mathrm{mL})$, E. Combination Extract and Vancomycin $(300 \mathrm{mg} / \mathrm{mL}$ : 16 $\mu \mathrm{g} / \mathrm{mL})$, F. Combination Extract and Vancomycin $(600 \mathrm{mg} / \mathrm{mL}$ : $16 \mu \mathrm{g} / \mathrm{mL}$ )

Table 1. The FICI of the test material after overnight incubation

\begin{tabular}{|c|c|c|c|c|}
\hline \multirow{2}{*}{ Concentration } & \multicolumn{4}{|c|}{ Red betel extract $(\mathrm{mg} / \mathrm{mL})$} \\
\hline & $\mathbf{0}$ & $\mathbf{1 2 . 5}$ & 50 & 200 \\
\hline & 0.003 & 0.010 & 0.008 & 0.018 \\
\hline  & 0.003 & 0.014 & 0.007 & 0.004 \\
\hline ¿ी 16 & 0.016 & 0.013 & 0.003 & 0.004 \\
\hline$\stackrel{\pi}{>}^{2} 32$ & 0.012 & 0.004 & 0.003 & 0.007 \\
\hline
\end{tabular}


Staphylococcus aureus bacteria were well-grown on test media without visible contamination of other microorganisms. Vancomycin activity against $S$. aureus could be demonstrated using the test method used. The results of the diffusion test showed that red betel extract could inhibit the growth of $S$. aureus starting at 150 $\mathrm{mg} / \mathrm{mL}$. The combination of red betel extract and vancomycin $(150 \mathrm{mg} / \mathrm{mL}: 16 \mu \mathrm{g} / \mathrm{mL})$ showed an increase in $S$. aureus growth inhibition compared to the single vancomycin or extract. The increase in antibacterial effects suggests that a combination of red betel extract with vancomycin produces a synergistic effect. The synergy effect occurs when an effect seen by a combination of substances is greater than those of individual contributions (Williamson 2001). Several studies reported the synergistic effect of antibiotics when the antibiotics were combined with natural ingredients. The synergistic effect occurred on chloramphenicol activity combined with Piper betle, L towards the $S$. aureus (Taukoorah et al. 2016). The addition of pineapple extract to vancomycin increased the antibacterial effects of the antibiotic (Kosropanah et al. 2012).

The addition of 150,300 , or $600 \mathrm{mg} / \mathrm{mL}$ red betel extract to vancomycin $16 \mu \mathrm{g} / \mathrm{mL}$ showed a synergistic effect. The addition of various concentrations of extracts to vancomycin did not always result in an increase of synergistic effects. In comparison with the $150 \mathrm{mg} / \mathrm{mL}$ extract, the addition of $300 \mathrm{mg} / \mathrm{mL}$ extract to vancomycin $16 \mu \mathrm{g} / \mathrm{mL}$ did not bring any significant difference in the activity. While the addition of $600 \mathrm{mg} / \mathrm{mL}$ extract to vancomycin showed a significant decrease in the activity against $S$. aureus. This result suggested that the addition of red betel $150 \mathrm{mg} / \mathrm{mL}$ extract to $16 \mu \mathrm{g} / \mathrm{mL}$ vancomycin produced an optimal antibacterial effect.

The result of antibacterial activity using the microdilution checkerboard method confirmed the type of synergistic effect from the red betel extract in combination with vancomycin, with FICI value of 0.325 (Table 1). The value of MIC vancomycin in combination with red betel extract decreased 4-fold. This reduction is greater than the combination of vancomycin with the Carum copticum. Vancomycin in combination with $C$. copticum essential oils reduced MIC from 0.5 to $0.12 \mu \mathrm{g} / \mathrm{m}$ (Talei et al. 2017). The microdilution checkerboard method test results also confirmed that the increase of extract concentration in the combination of extract and vancomycin did not always result in an increase of synergy effects. The addition of red betel extract $12.5,50$, or $200 \mathrm{mg} / \mathrm{mL}$ to $4 \mu \mathrm{g} / \mathrm{mL}$ or 16 $\mu \mathrm{g} / \mathrm{mL}$ vancomycin showed an increase in synergistic effect characterized by a decrease in absorbance of the test material. However, the addition red betel extracts did not result in an increase in the synergistic effect of $32 \mu \mathrm{g} / \mathrm{mL}$ vancomycin, the consistent absorbance value of test material indicated the constant inhibition of $S$. aureus growth.

The antibacterial activity of $200 \mathrm{mg} / \mathrm{mL}$ red betel extract and $4 \mu \mathrm{g} / \mathrm{mL}$ or $16 \mu \mathrm{g} / \mathrm{mL}$ vancomycin combination did not have any significant difference, however, both combinations showed the highest inhibitory activity of $S$. aureus growth. Since the results of the diffusion test showed that the antibacterial activity of the combination of red betel extract $300 \mathrm{mg} / \mathrm{mL}$ did not differ significantly with the $150 \mathrm{mg} / \mathrm{mL}$, therefore the recommended concentration of red betel extract is $200 \mathrm{mg} / \mathrm{mL}$. Since the addition of $12.5,50$, or $200 \mathrm{mg} / \mathrm{mL}$ red betel extract on vancomycin $32 \mu \mathrm{g} / \mathrm{mL}$ did not significantly different, therefore the best-recommended combination for obtaining the highest antibacterial activity against $S$. aureus was 200 $\mathrm{mg} / \mathrm{mL}$ red betel extract with $4 \mu \mathrm{g} / \mathrm{mL}$ vancomycin.

Vancomycin is one of the glycopeptide class antibiotics. Glycopeptide class antibiotics involved in cellwall biosynthesis which binds the substrate of transpeptidase enzyme. Therefore, the enzymes are potential targets for combating the resistance (Healy et al. 2000). The essential oils of red betel leaves has activity to inhibit $S$. mutans by inhibiting the activity of glucosyltransferase (Erviana et al. 2011). Combinations of compounds have been used in various treatments such as hypertension therapy, atherosclerosis, type-2 diabetes mellitus, cancer, and tuberculosis (Williamson 2010). The combined effect of the compound can be utilized to produce intended harmful effects to anti fungi, or unintended harmful effects, such as for synergistic toxicity (Bulusu et al. 2016). The compounds combination may lead to new ways to treat $S$. aureus (Moussaoui and Alaoui 2015). There has been a report on the additive effect in the combination of Quercus infectoria galls and vancomycin. A possible mechanism of antimicrobial action triggered by the combination treatments was postulated to be associated with the same target sites of the bacterial cell wall (Basri and Khairon 2012). Several compounds isolated from red betel have been reported, namely essential oil (Erviana et al. 2011), neolignans (Hartini et al. 2014), $\beta$-sitosterol and d 2- (5 ', 6'-dimethoxy-3', 4'- methylenedioxyphenyl) -6- (3 ", 4", 5 "-trimethoxyphenyl) -3.7-dioxabicyclo [3,3,0] octane (Emrizal et al. 2014), however, there were no reports of antimicrobial activity combined with red betel compounds.

Evaluation of vancomycin combination with antibiotics both in vitro and in animal models of infection often yields inconsistent results, however, there are no data available from randomized clinical trials to support their use, while some regimens are known to have potential toxicities (Deresinski 2009). The multi-component nature of medicinal herbs makes them particularly suitable for treating complex diseases and offers great potential for exhibiting synergistic actions. Different agents may regulate either the same or different target in various pathways and therefore cooperate in an agonistic or synergistic way (Yang et al. 2014). Therefore, the results of this research have the potential to be further developed to discover a combination of compounds that can overcome the problem of $S$. aureus resistance to vancomycin.

The addition of red betel extract to vancomycin produces a synergistic effect, which decreases the MIC value to 1/4 of single MIC vancomycin against $S$. aureus. Moreover, the FICI value of red betel extract and vancomycin combination was 0.3125 . The bestrecommended combination for obtaining the highest 
antibacterial activity against $S$. aureus is the combination of $200 \mathrm{mg} / \mathrm{mL}$ red betel extract and $4 \mu \mathrm{g} / \mathrm{mL}$ vancomycin.

\section{ACKNOWLEDGEMENTS}

The authors are grateful to Sanata Dharma University, Yogyakarta, Indonesia, for financial support.

\section{REFERENCES}

Aldulaimi OA. 2017. General overview of phenolics from plant to laboratory, good antibacterial or not. Pharmacognosy Rev 11 (22): 123-127.

Basri DF, Khairon R. 2012. Pharmacodynamic interaction of Quercus infectoria galls extracts in combination with vancomycin against MRSA using microdilution checkerboard and time-kill assay. Evidence-Based Complement Altern Med 493156: 1-6.

Bulusu KC, Guha R, Mason DJ, Lewis RPI, Muratov E, Motamedi YK, Cokol M, Bender A. 2016. Modelling of compound combination effects and applications to efficacy and toxicity: state-of-the-art, challenges and perspectives. Drug Discov Today 2: 225-238.

Chambers HF, DeLeo FR. 2009. Waves of resistance: Staphylococcus aureus in the antibiotic era. Nat Rev Microbiol 7 (9): 629-641.

Cheesmas MJ, Ilanko A, Blonk B, Cock IE. 2017. Developing new antimicrobial therapies: Are synergistic combinations of plant extracts/compounds with conventional antibiotics the solution? Pharmacognosy Rev 11: 57-72.

Demetrio L, Valle Jr, Andrade JI, Puzon JM, Cabrera EC, Rivera WL. 2015. Antibacterial activities of ethanol extracts of Philippines medicinal plants against multi drugs-resistant bacteria. Asian Pac J Trop Biomed 7: 532-540.

Deresinski S 2009. Vancomycin in combination with other antibiotics for the treatment of serious methicillin-resistant Staphylococcus aureus infection. Clin Infect Dis 49 (7): 1072-1079.

Emrizal, Fernando A, Yuliandri R, Rullah K, Indrayani NR, Susanty A, Yerti R, Ahmad F, Sirat HM, Arbain D. 2014. Cytotoxic Activities of Fractions and Two Isolated Compounds from Sirih Merah (Indonesian red betel), Piper crocatum Ruiz \& Pav. Procedia Chem 13: 79-84.

Erviana R, Purwono S, Mustofa. 2011. Active compounds isolated from red betel (Piper crocatum Ruiz \& Pav) leaves active against Streptococcus mutans through its inhibition effect on glucosyltransferase activity. J Med Sci 2: 71-78

Hartini YS, Wahyuono S, Widyarini S, Yuswanto A. 2014. In vivo immunomodulatory effect and histopathological features of mouse liver and kidney treated with neolignans isolated from red betel (Piper crocatum Ruiz \& Pav). Leaf. Trop J Pharm Res 13 (10): 1609-1614.
Hasan R, Acharjee M, Noor R. 2016. Prevalence of vancomycin-resistant Staphylococcus aureus (VRSA) in methicillin-resistant S. aureus (MRSA) strains isolated from burn wound infections. Ci Ji Yi Xue Za Zhi 28: 49-53

Healy VL, Lessard IAD, Roper DI, Knox JR, Walsh CT. 2000. Vancomycin resistance in enterococci: reprogramming of the D-AlaD-Ala ligases in bacterial peptidoglycan biosynthesis. Chem Biol 7 (5): 109-119.

Jain SN, Vishwanatha T, Reena V, Divyashree BC, Aishwarya S, Siddhalingeswara KG, Venugopal N, Ramesh I. 2011. Antibiotic Synergy Test: Checkerboard Method on Multidrug-Resistant Pseudomonas aeruginosa. Int Res J Pharm 2 (12): 196-198.

Kosropanah H, Bazargani A, Ebrahimi H, Eftekhar K, Emami Z, Esmailzadeh S. 2012. Assessing the effect of pineapple extract alone and in combination with vancomycin on Streptococcus sanguis. Jundishapur J Nat Pharm Prod 7 (4): 140-143.

Kusuma ASF, Zuhrotun A, Meidina FB. 2016. Antibacterial spectrum of ethanol extract of Indonesian red piper betel leaf (Piper crocatum Ruiz \& Pav) against Staphylococcus species. Int J Pharma Sci Res 7 (11): 448-452.

Leclerecq R. 2009. Epidemiological and resistance issues in multidrugresistant staphylococci and enterococci. Clin Microbiol Infect 15: 224-231.

Moussaoui F, Alaoui T. 2015. Evaluation of antibacterial activity and synergistic effect between antibiotics and the essential oils of some medicinal plants. Asian Pac J Trop Biomed 6 (1): 32-37.

Nosten F, White NJ. 2007. Artemisinin-based combination treatment of falciparum malaria. Am J Trop Med Hyg 77 (Suppl 6): 181-192.

Nugroho LH, Sutikno, Susandarini R, Yuliati IR, Priyono Y, Munawaroh E, Astuti IP. 2019. Comparative leaf and stem anatomy of ten Piper species form Indonesia. Asian J Agric Biol 7 (3): 434-441.

Ramon-Garcia S, Carol Ng, Anderson H, Chao JD, Zheng X, Gay Y, Roberge M, Thompsom. 2011. Synergistic Drug Combinations for tuberculosis therapy identified by a novel high-throughput screen. Antimicrob Agents Chemother 55 (8): 3861-3869.

Semeniuc CA, Pop CR, Rotar AM. 2013. Antibacterial activity and interactions of plant essential oils combinations against Gram-positive and Gram-negative bacteria. J Food Drug Anal 25: 403-408.

Talei GR, Mohammadi M, Bahmani M, Kopaei MR. 2017. Synergistic effect of Carum copticum and Mentha piperita essential oils with ciprofloxacin, vancomycin, and gentamicin on Gram-negative and Gram-positive bacteria. Int J Pharma Investig 7: 82-87.

Taukoorah U, Lall N, Mahomoodally F. 2016. Piper betle L. (betel quid) shows bacteriostatic, additive, and synergistic antimicrobial action when combined with conventional antibiotics. South Afr J Bot 105: 133-140.

Williamson EM. 2001. Synergy and other interactions in phytomedicines. Phytomedicine 8: 401-409.

Yang Y, Zhang Z, Li S, Ye X, Li X, He K. 2014. Synergy effects of herbs extracts: Pharmacokinetics and pharmacodynamics basis. Fitoterapia 92: 133-147. 